\title{
Feeding effects of cottonseed and its co-products on the meat proteome from ram lambs
}

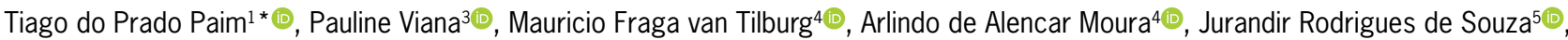

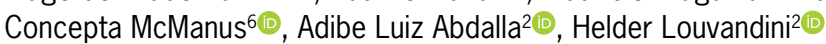

IInstituto Federal de Educação, Ciência e Tecnologia Goiano, Av. Oeste, 350 - 76200-000 - Iporá, GO - Brasil.

2Universidade de São Paulo/CENA - Lab. Nutrição Animal, Av. Centenário, 303 - 13416-000 - Piracicaba, SP - Brasil. 3Universidade de Brasilia/Faculdade de Agronomia e Medicina Veterinária, Ala Central do Instituto Central de Ciências - 70910-900 - Brasília, DF - Brasil.

${ }^{4}$ Universidade Federal do Ceará - Depto. de Zootecnia, C.P. 12168 - 60970-355 - Fortaleza, CE - Brasil.

${ }_{5}^{5}$ Universidade de Brasília/Instituto de Química - Lab. de Química Analítica e Ambiental, C.P. 04478.

UUniversidade de Brasília/Instituto de Ciências Biológicas, C.P. 04508

*Corresponding author <pradopaim@hotmail.com>

Edited by: Paulo Cesar Sentelhas

Received March 12, 2018

Accepted June 20, 2018
ABSTRACT: Gossypol easily pairs with lysine side chains and enzymes involved in the cellular growth process. The effect of gossypol (a compound present in cotton co-products) in ruminant metabolism and meat quality is not yet clear. This study was undertaken in order to evaluate the effects of cotton co-products in lamb muscle proteome. Twenty-four Santa Inês ram lambs, 5-months old $(20.6 \pm 1.9 \mathrm{~kg})$, were randomly assigned to four treatments: control (without cottonseed), whole cottonseed, cottonseed meal and high oil cottonseed meal. At 95 days into the experiment, lambs were slaughtered and samples from Longissimus dorsi were collected. Proteins were extracted and analyzed by 2-D electrophoresis. Spots showing a significant effect from the treatment (the "treatment effect") and present in more than $90 \%$ of the samples were identified using mass spectrometry. Cotton co-products decreased the abundance of aldehyde and malate dehydrogenases, creatine kinase M-type and Adenosine triphosphate (ATP) synthase. They also increased four proteins related to muscle contraction. Thus, feeding cotton co-products to lambs changed the abundance of important muscle proteins. A cotton co-product diet induced a negative impact on the energy supply of muscle cells and, consequently, the abundance of ATP dependent proteins (contractile apparatus) increased, probably in order to offset and maintain muscle function. These proteomic changes can promote our understanding of alterations in the sensorial properties of meat due to cotton co-product diets in further investigations. Keywords: gossypol, dehydrogenase, skeletal muscle, sheep, feedlot

\section{Introduction}

Whole cottonseed and its co-products are alternative feed sources for ruminants (Silva et al., 2016). This is an interesting feed because of its association of high protein content with high energy content, which permits the formulation of low-cost diets (Cranston et al., 2006). However, a major limitation for using cottonseed in animal nutrition is the presence of high levels of gossypol, which is a toxic compound that reacts with primary amines, and leads to the formation of gossypol imines or Schiff bases (Gadelha et al., 2014). The biological activity of gossypol in mammals has been characterized by its easy coupling to lysine side chains of proteins and enzymes involved in the cellular growth process (Dao et al., 2000). In cattle, whole cottonseed was associated with problems in meat flavor (Costa et al., 2013), mainly liver-like flavor. However, the mechanisms associated with this problem are not yet clear.

Gossypol and its analogs were studied for a broadspectrum of biological activities, including anti-parasitic, anti-malarial, anti-HIV and anticancer (Zhang et al., 2009). Gossypol is a promoter of free radical formation and much of its cytotoxicity has also been attributed to gossypolone, which represents the main in vivo metabolite of gossypol (Dao et al., 2000).

Replacement of soybean meal by cottonseed meal in hen feed reduced fifteen egg white proteins, causing adverse effects on albumen quality (He et al., 2017). In ruminants, the type of diet (more roughage or more grains) can alter the gossypol metabolism and conse- quently impact the outcome of carcass traits and, thus, the meat quality (Oliveira et al., 2015). Therefore, the effect of gossypol in ruminant metabolism and meat quality remains unclear, including possible changes in enzyme activity and proteomic profile. Therefore, the aim of this study was to evaluate whether feeding cotton co-products to lambs can change the muscle proteome and if it can affect the muscle metabolism and the conversion of muscle to meat.

\section{Materials and Methods}

\section{Experimental design}

The animal care and use committee (protocol $33 / 2009$ ) approved the experiment. Twenty-four Santa Inês ram lambs (5-months old, $20.6 \pm 1.9 \mathrm{~kg}$ ) were housed in shaded individual pens as described by Paim et al. (2014). Four treatments were randomly assigned to the experimental units (lambs) in a complete randomized design. The treatments were control diet without cottonseed (CTL); whole cottonseed (WCS); solvent-extracted cottonseed meal (CSM); and pressure-extracted high oil cottonseed meal (CSC) (Table 1).

Diets were calculated based on a fixed concentrate:forage ratio (50:50) aiming for $200 \mathrm{~g} \mathrm{~d}^{-1}$ of body weight gain following NRC (2007) requirements (Table 1). The forage source was Coast cross hay (Cynodon dactylon (L.) Pers). All groups received equal quantities of mineral salt $\left(20 \mathrm{~g} \mathrm{~kg}^{-1}\right)$ and urea $\left(27 \mathrm{~g} \mathrm{~kg}^{-1}\right)$. The fat level in diets was equilibrated by adding soybean oil to the concentrate in CTL, CSM and CSC groups (Table 1). 
Table 1 - Experimental diet formulation, chemical composition (on dry matter basis) and free gossypol content.

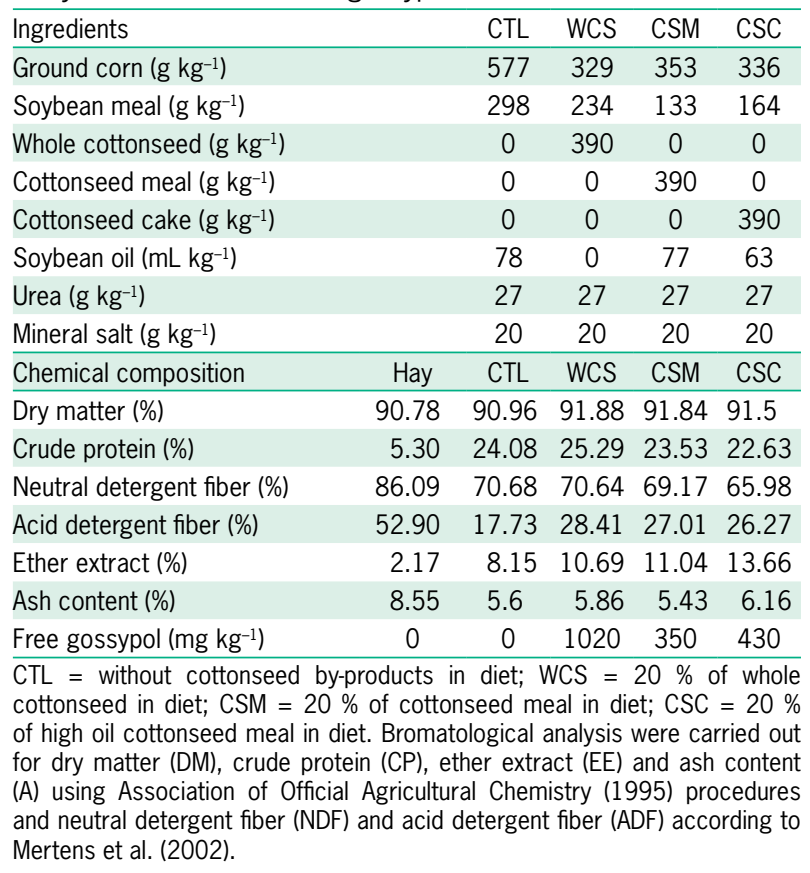

Lambs were fed two times per day $108 \mathrm{~h} 00$ and 17h00), and the feed offered was adjusted daily aiming for orts equal to $10 \%$ of offer. Animals were weighed every 15 days during the experiment, after a 12-h fast. The animals remained 109 days in the feedlot, consisting of a 14 day adaptation period and 95 days of experimentation.

Free gossypol concentrations in diets were measured by the UV-VIS spectrophotometry method according to Wang (1987) and Botsoglou (1991). Ground diet samples $(200 \mathrm{mg})$ were mixed with $10 \mathrm{~mL}$ of $70 \%$ aqueous acetone; $16 \mathrm{~h}$ later, $5 \mathrm{~mL}$ of $70 \%$ aqueous acetone were added and shaken for $30 \mathrm{~min}$. The mixture was filtered through filter paper and the residue washed three times with $2 \mathrm{~mL}$ of $70 \%$ aqueous acetone each. The filtrate was evaporated to dryness in a nitrogen stream. The remaining residue was dissolved with $10 \mathrm{~mL}$ of chloroform:acetic acid $(99: 1, \mathrm{v} / \mathrm{v})$ and refiltered through a $0.2 \mu \mathrm{m}$ nylon membrane. The filtrate was analyzed in high performance liquid chromatography (HPLC) using the $\mathrm{C} 18$ column $(250 \times 4.6 \mathrm{~mm})$. The wavelength detected was $254 \mathrm{~nm}$.

\section{Sample collection}

At the end of the experiment, lambs were weighed and slaughtered at a commercial abattoir after a 24-h fast, according to Brazilian law (MAPA, 1980). After bleeding and evisceration, carcasses were kept at 2-4 ${ }^{\circ} \mathrm{C}$ for $24 \mathrm{~h}$. Samples from the Longissimus dorsi muscle were collected $24 \mathrm{~h}$ post-mortem and frozen $\left(-20^{\circ} \mathrm{C}\right)$ for protein extraction.
Protein extraction from Longissimus dorsi muscle Samples of Longissimus dorsi muscle were minced and stored in sterile tubes at $-20{ }^{\circ} \mathrm{C}$ until protein extraction, in accordance with Sanchez et al. (2001). Five milligrams of each muscle sample were placed in $100 \mu \mathrm{L}$ of 1 $\%$ of TRITON-X 100 in ultra-purified water and refrigerated at $5^{\circ} \mathrm{C}$ for $1 \mathrm{~h}$. Then, a $400 \mu \mathrm{L}$ of sample buffer was added (7 M Urea, $2 \mathrm{M}$ thiourea, 4 \% 3-[(3-cholamidopropyl) dimethylammonio]-1-propanesulfonate (CHAPS), 2 $\%$ buffer IPG pH 4 - 7, 40 mM DTT [dithiothreitol]). Samples were sonicated for $5 \mathrm{~min}\left(4^{\circ} \mathrm{C}\right)$ and centrifuged thereafter $\left(5,000 \mathrm{~g}, 60 \mathrm{~min}, 4^{\circ} \mathrm{C}\right)$, retaining the supernatant. Total protein was determined by Bradford's method (Bradford, 1976), running in triplicate and using bovine serum albumin as standard.

\section{Two-dimensional electrophoresis}

Two-dimensional electrophoresis was carried out as previously described (Oliveira et al., 2015; Van Tilburg et al., 2013). Briefly, for the first dimension, $400 \mu \mathrm{g}$ of Longissimus dorsi proteins were mixed with $250 \mu \mathrm{L}$ of buffer ( $7 \mathrm{M}$ urea, $2 \mathrm{M}$ thiourea, $2 \%$ free ampholytes, 2 $\%$ CHAPS, and $2 \times 10^{-3} \%$ of bromophenol blue). The mix was incubated with 13-cm IPG strips ( $\mathrm{pH} 4-7$, linear) and rehydrated for $14 \mathrm{~h}$. Isoelectric focusing was carried out in an ETTAN IPGphor III isoelectric focusing system at $20{ }^{\circ} \mathrm{C}$, according to the following sequence: $100 \mathrm{~V}$ for $30 \mathrm{~min}, 250 \mathrm{~V}$ for $1 \mathrm{~h}, 500 \mathrm{~V}$ for $1 \mathrm{~h}, 8,000 \mathrm{~V}$ for $2.5 \mathrm{~h}$, totaling 50,000 Vh (Van Tilburg et al., 2013). After focusing, IPG strips were incubated for $20 \mathrm{~min}$ in an equilibration buffer I (6 M urea, $75 \mathrm{mM}$ Tris $\mathrm{pH} 8.8$, $29 \%$ glycerol, $2 \%$ SDS, $1 \%$ DTT) and reequilibrated for an additional $20 \mathrm{~min}$ in buffer II (similar to equilibration buffer I, but containing $5 \%$ iodoacetamide instead of DTT). After equilibration, the proteins were separated using SDS-PAGE (13\%) and run at $500 \mathrm{~V}$, with $20 \mathrm{~mA}$ per gel (Hoefer SE 600). Low molecular weight markers $(14.4 ; 20.1 ; 30.0 ; 45.0 ; 66.0 ; 97.0 \mathrm{Da})$ were used. Gels were stained in colloidal Coomassie blue (van Tilburg et al., 2013). In summary, gels were fixed in a solution containing phosphoric acid $(2 \%)$ and ethanol (30\%) overnight and washed three times for $20 \mathrm{~min}$ in $2 \%$ phosphoric acid. Then, they were placed in another solution $(2 \%$ phosphoric acid, $18 \%$ ethanol and $15 \%$ ammonium sulfate) for $30 \mathrm{~min}$ followed by the addition of $2 \mathrm{~mL}$ of a Coomassie Blue G-250 solution (2\%) for $72 \mathrm{~h}$.

\section{Gel analysis}

Two-dimensional gels were scanned at $300 \mathrm{dpi}$ and analyzed using the PDQuest software package (version 7.3.0; Bio-Rad). A master gel was generated to evaluate all 2-D maps in a single match (Moura et al., 2006; Oliveira et al., 2015). Spots consistently present in the remaining gels were added to the master. Each spot in each gel was checked with the respective pattern in the master gel. Based on PDQuest guidelines, protein abundances were given as parts per million of the total integrated optical density of spots in the gels. 


\section{Statistical analysis}

Spot intensities were analyzed using a mixed model (MIXED procedure) in the SAS 9.3 program (SAS Institute, Cary, NC, USA). This model considered treatment as the fixed effect and animal as the random effect. Least square means with Tukey adjustment were used to compare means when a significant treatment effect $(p$ $<0.05$ ) was observed. The effect of free gossypol level (concentration in total diet) on proteins was tested using a regression model (REG procedure; $\mathrm{SAS}^{\circledR}$ ). Linear, quadratic and cubic effects of gossypol level were tested through a stepwise selection method to determine the model that best fitted the results of protein abundance. The significant level for the dependent variable to remain in the model was set at $p<0.05$. Discriminant and factor analyses (DISCRIM and FACTOR procedures in $\mathrm{SAS}^{\circledR}$, respectively) were carried out to identify which spots were able to discriminate between the treatments and the relation between the spots, respectively. Protein identification was carried out on spots showing significant treatment effects in analysis of variance or significant regression with gossypol level. Spots missed in more than $10 \%$ of samples (animals) were not used for protein identification. As some spots appeared only in a few animals, this restriction was used to avoid bias due to small experimental sample.

\section{Protein identification using electrospray ionization quadrupole-time-of-flight mass spectrometry}

The selected spots were identified by tandem mass spectrometry following the method used by Van Tilburg et al. (2013). The spots were removed from gels and washed three times with $400 \mu \mathrm{L}$ of acetronitrile $(50 \%)$ and ammonium bicarbonate $(50 \% ; 25 \mathrm{mM}$ at $\mathrm{pH} 8.0)$. Then, the pieces were passed through a double wash with $200 \mu \mathrm{L}$ of acetonitrile for $5 \mathrm{~min}$ followed by airdrying at room temperature. After, a trypsin (166 ng per spot) incubation for $20 \mathrm{~h}$ at $37^{\circ} \mathrm{C}$ was carried out. At the end, peptides were extracted using three washings with $5 \%$ trifluoroacetic acid, $50 \%$ acetonitrile, and ammonium bicarbonate $(50 \mathrm{mM})$ and concentrated using a speed vacuum concentrator.

Chromatographic separation was carried out using a UPLC C18 column $(75 \mu \mathrm{m} \times 10 \mathrm{~cm})$ with a flow of $0.6 \mu \mathrm{L} \mathrm{min}{ }^{-1}$. A nanoAcquity UPLC sample manager was used to inject the digested samples. The mass spectra were acquired in a Synapt G2 HDMS Acquity UPLC instrument. Three top peaks were subjected to MS/MS. Mobile phases A and B were $10^{-1} \%$ formic acid in water and $10^{-1} \%$ formic acid in acetonitrile, respectively. The gradient conditions used were 0 minutes with $3 \%$ of $\mathrm{B}$; increasing linearly to $30 \% \mathrm{~B}$ in $20 \mathrm{~min}$; then up to 70 $\% \mathrm{~B}$ in $40 \mathrm{~min}$, remaining there for $50 \mathrm{~min}$; and then decreasing to $3 \%$ of $\mathrm{B}$.

Data were subjected to a database search using a MASCOT search engine (http://www.matrixscience. com). The searches were made on the assumption that there were a maximum of one missed trypsin cleavage, partially oxidized methionine residues, completely carbamidomethylated cysteine residues, and that peptides were monoisotopic. Peptide and fragment mass tolerance were set to $\pm 0.1 \mathrm{Da}$ for MS/MS ion searching. When manually reviewing MASCOT search results, the candidate peptide identifications were only accepted if the $\mathrm{m} / \mathrm{z}$ values observed were within $0.1 \mathrm{Da}$ (typically less than $0.05 \mathrm{Da}$ ) of the theoretical mass of the candidate protein.

\section{In silico analysis of protein interactions}

The proteins identified by mass spectrometry were submitted to protein-protein interaction analysis, considering known and predicted interactions, using the STRING biological database (http://string-db.org), version 9.1 (Rego et al., 2014). Bos taurus was set as the organism (as Ovis aries is not available). Only proteins with a confidence score above 0.90 were selected for analysis. Interactions in evidence were based on co-expression (black lines), databases (light blue), text-mining (yellow), and experimental (purple) data. Interactions in action mode represent reaction (black lines), binding (blue), or catalysis (purple).

\section{Results}

The average daily weight gain was $138 \pm 8.0 \mathrm{~g} \mathrm{~d}^{-1}$, without any treatment effect. The estimated free gossypol (FG) intake per treatment was 0,16.32, 6.98 and $5.47 \mathrm{mg} \mathrm{kg}^{-1}$ of body weight (BW) for CTL, WCS, CSC and CSM, respectively (Table 1 ).

An average of $170 \pm 32.4$ protein spots was detected after analysis of 24 gels with proteins extracted from Longissimus dorsi (Figure 1). Twenty-nine spots were differentially expressed between treatments and 22 spots yielded significant relationships with gossypol levels in the diet, as determined by regression analysis (Table 2). Figure 2 shows the least square means for protein abundances of the spots showing treatment effects $(p<0.05)$ which appeared in more than $90 \%$ of the samples. Table 3 describes the regression indices for linear, quadratic and cubic effect of gossypol on protein abundances.

Twenty spots discriminated correctly the animals into their respective treatment group $(100 \%$ of the animals were correctly located in their group). These spots were $36,9,49,14,25,19,48,35,21,24,2,17,37$ and 1 , following the order they entered in the model. The first factor (Figure 3) demonstrated a group of spots $(11,39$, $8,29$ and 47$)$ that increased in intensity while others (26 and 31) decreased. The second factor showed another group of spots $(20,27,50,13,38$ and 32$)$ that increased in intensity when spots 3,4 and 6 decreased.

Eleven protein spots that differed between treatments were identified as eight muscle proteins (Table 4). All these spots were present in at least $90 \%$ of the samples. Spots 4 and 12 were identified as actin of alpha skeletal muscle (ACTA1) and both spots presented a positive cubic regression effect in relation to gossypol 


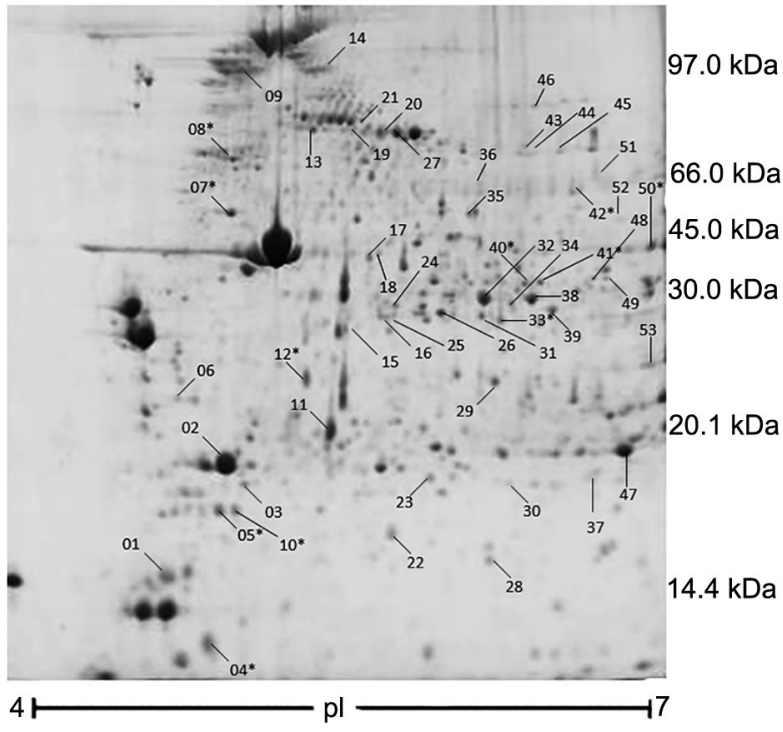

Figure 1 - 2-D map of proteins of the Longissmus dorsi muscle from lambs fed with cotton co-products. The map represents the master gel generated by the software package (version 7.3.0; Bio-Rad), based on a matched set with all gels used in the study. Proteins were stained with Coomassie blue and identified using mass spectrometry. ${ }^{*}$ Refers to those spots identified and shown in Table 4; $\mathrm{pl}=$ isoelectric point.

level in the diet (Table 3). The WCS diet (1020 mg kg-1) had more than twice the free gossypol concentration than CSM and CSC (350 and $430 \mathrm{mg} \mathrm{kg}^{-1}$, respectively). This can yield significant cubic regression in the range of free gossypol concentration evaluated, depending on the shape of the regression curve, such as, for example, a plateau between CSM and CSC.

Spot 8 was identified as alpha-actinin-3 (ACTN3) and its intensity in the 2-D gels had a positive quadratic association with the gossypol level in the diet (Table 3). Spots 5, 40 and 41 represented troponin T of fast skeletal muscle (TNNT3). The control group had a lower expression of spot 5 compared to other animals. Spot 5 also had a positive linear relation with gossypol levels of the diets. Control animals had a lower content of spot 40 in comparison with rams of CSC and CSM treatments. The CSC group had a greater expression of spot 41 than CTL and WCS groups. Spot 10 was identified as a myosin light chain (MYL1) and its intensity also had a positive and linear association with certain levels of dietary gossypol. Creatine kinase M-type (CKM) demonstrated a negative linear regression with gossypol level in diet. CKM appeared in the factor analysis (Factors 1 and 2) in opposition to ACTN3 and ACTA1, showing that when the first decreased, the others increased, and vice-versa. In silico analysis of interactomes showed associations (evidence and action) between TNNT3, ACTN3, MYL1 and CKM. Additionally, TNNT3 presented binding action with ACTN3, CKM and MYL1.
Table 2 - Summary of statistical analysis using mixed model (MIXED) and regression (REG) analyses, evaluating the effect of co-products fed to lambs on protein (spot) abundance from muscle samples.

\begin{tabular}{|c|c|c|c|c|c|}
\hline \multirow{2}{*}{ Spot number } & \multirow{2}{*}{$\begin{array}{c}\text { MIXED } \\
\text { (p-value) }\end{array}$} & \multicolumn{3}{|c|}{ REG (p-value) } & \multirow{2}{*}{ - Frequency ${ }^{1}$} \\
\hline & & gos & $\operatorname{gos}^{2}$ & gos $^{3}$ & \\
\hline & & & & & $\%$ \\
\hline 4 & 0.073 & ns & ns & 0.0201 & 100 \\
\hline 5 & 0.001 & 0.0184 & ns & ns & 96 \\
\hline 7 & 0.0669 & 0.047 & ns & ns & 100 \\
\hline 8 & 0.0787 & ns & 0.0092 & ns & 100 \\
\hline 9 & 0.0068 & ns & ns & 0.0008 & 52 \\
\hline 10 & 0.0515 & 0.0421 & ns & ns & 96 \\
\hline 12 & ns & ns & ns & 0.0218 & 100 \\
\hline 16 & 0.0317 & ns & ns & ns & 61 \\
\hline 22 & 0.0271 & ns & ns & 0.0091 & 78 \\
\hline 23 & 0.0403 & ns & ns & ns & 70 \\
\hline 25 & 0.0257 & ns & ns & ns & 48 \\
\hline 30 & 0.0326 & ns & ns & ns & 48 \\
\hline 33 & 0.0256 & ns & 0.0031 & ns & 100 \\
\hline 34 & ns & 0.0254 & ns & ns & 48 \\
\hline 36 & 0.0018 & ns & ns & ns & 57 \\
\hline 40 & 0.0087 & ns & ns & ns & 91 \\
\hline 41 & 0.0204 & ns & ns & ns & 96 \\
\hline 42 & 0.0415 & ns & 0.0057 & ns & 96 \\
\hline 43 & ns & ns & ns & 0.0335 & 74 \\
\hline 44 & ns & ns & ns & 0.0232 & 87 \\
\hline 45 & 0.0943 & 0.0102 & ns & ns & 87 \\
\hline 46 & 0.0599 & ns & ns & 0.0262 & 74 \\
\hline 49 & 0.0037 & 0.0142 & 0.0275 & ns & 61 \\
\hline 50 & 0.0866 & 0.0238 & ns & ns & 91 \\
\hline 51 & 0.0073 & ns & ns & 0.0009 & 78 \\
\hline 52 & 0.093 & ns & 0.0107 & ns & 74 \\
\hline 53 & 0.0184 & ns & ns & 0.0088 & 70 \\
\hline
\end{tabular}

Percentage of animals that presented spots; $\mathrm{ns}=$ not significant $(p>0.10)$. Spots highlighted in bold were selected for protein identification, as they occurred in more than $90 \%$ of samples and had $p<0.05$ in mixed model or by regression analysis. gos = linear effect of gossypol concentration in diet; gos $^{2}=$ quadratic effect of gossypol concentration in diet; gos ${ }^{3}=$ cubic effect of gossypol concentration in diet.

Chain D of Bovine Mitochondrial F1-Atpase complexed with Aurovertin B (ATP5B), spot 7, had a negative linear regression with certain gossypol levels. Spot 33 was identified as Malate dehydrogenase (MDH1), which was influenced by treatment and gossypol level in diet. The WCS group had lower MDH1 compared to CTL and CSM. MDH1 also presented a negative quadratic relationship with dietary levels of gossypol.

Spot 42, identified as Aldehyde dehydrogenase (ALDH1B1), showed lower expression in WCS compared to CTL and CSC. The intensity of spot 42 had a negative quadratic association with gossypol level in diet. ALDH1B1 interacts with some other detoxification enzymes, such as Aldose reductase (AKR1B1), Alcohol dehydrogenase (AKR1A1), Methylmalonate-semialdehyde dehydrogenase (ALDH6A1), Glutamate decarboxylase 1 (GAD1) and Gamma-amino-N-butyrate transaminase (ABAT). 


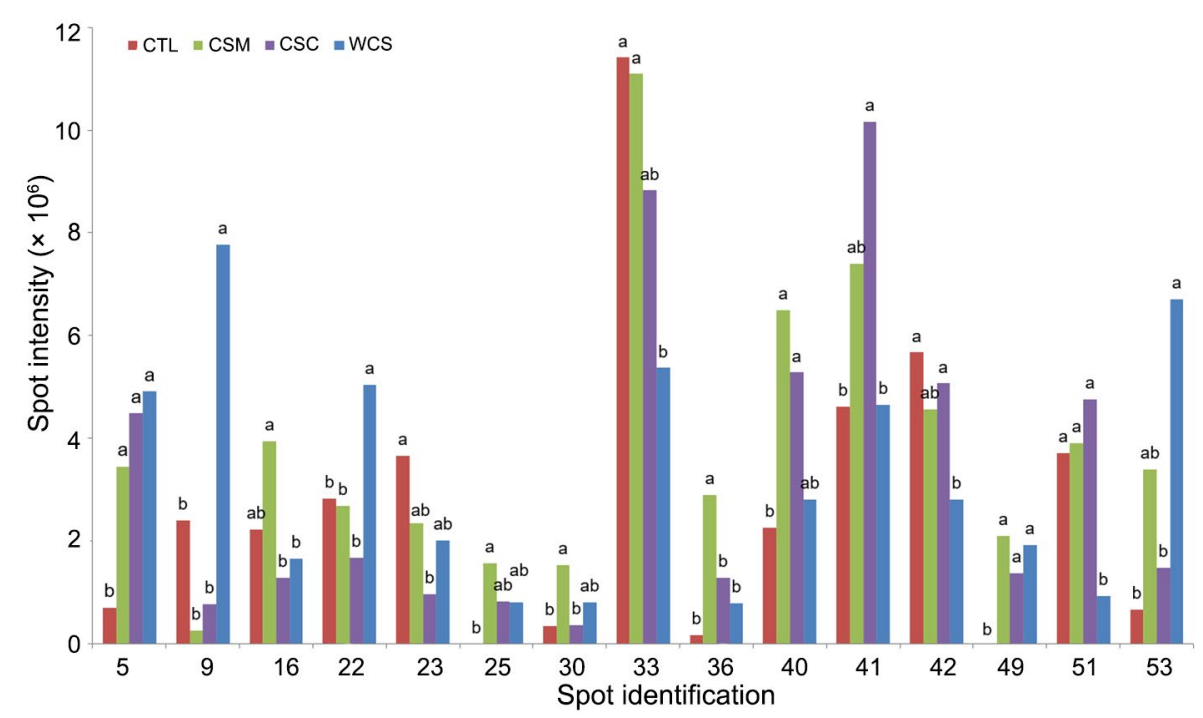

Figure 2 - Least square mean aırterences or proteın abunaances trom the LongIssmus aorsı muscie trom rambs tea with four diets: control without use of cottonseed (CTL), solvent-extracted cottonseed meal (CSM); pressure-extracted high oil cottonseed meal (CSC) and whole cottonseed (WCS). Different letters at same spot means statistical difference between treatments $(p<0.05)$.

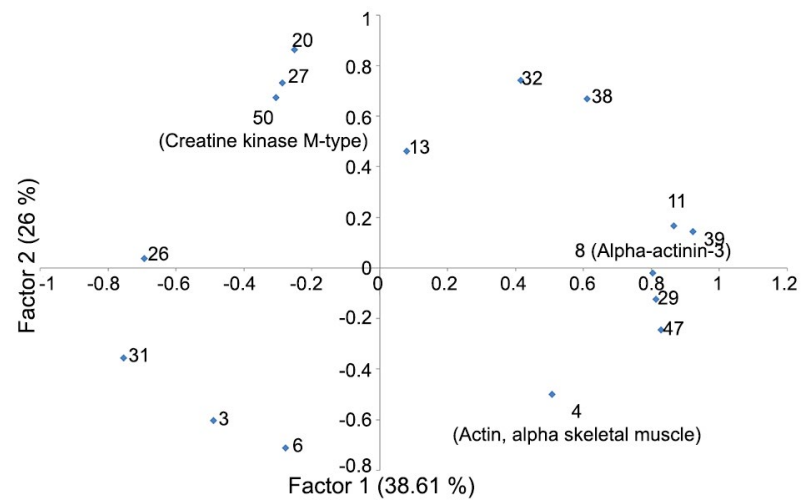

Figure 3 - Factor analysis of protein abundances from the Longissmus dorsi muscle from lambs fed with whole cottonseed, cottonseed meal with low oil, cottonseed meal with high oil and a control without use of cottonseed. The values in parentheses show the percentage of variance explained by each factor. The bold highlighted spots were identified by mass spectrometry.

\section{Discussion}

The directive 2002/32 of the European Union (2002L0032 - EN - 26.02.2013 - 017.001) states that the maximum free gossypol concentrations for complete feeding stuff are $100 \mathrm{ppm}$ for calves, and $500 \mathrm{ppm}$ for cattle, sheep, and goats. The WCS diet had 1,020 ppm of free gossypol and the other diets had less than $500 \mathrm{ppm}$. Therefore, only the WCS diet was above the adjudged safety guidelines.

Our previous results had shown that lambs fed with cottonseed meal have a higher hot carcass weight, carcass dressing and Longissimus dorsi muscle area than lambs receiving whole cottonseed. Meat from lambs
Table 3 - Regression coefficients for linear (gos), quadratic (gos²) and cubic $\left(\right.$ gos $^{3}$ ) effect of gossypol on protein abundance.

\begin{tabular}{lccccc}
\hline Spot & Intercept & gos & gos $^{2}$ & gos $^{3}$ & Model R \\
\hline $\mathbf{4}$ & $\mathbf{1 0 4 2 7 3 5 9}$ & & & 1400.197 & 0.2316 \\
5 & 3171371 & 200425 & & & 0.2374 \\
7 & 12253578 & -258032 & & & 0.1749 \\
8 & 1973135 & & 5498.109 & & $\mathbf{0 . 2 8 1 7}$ \\
9 & 813743 & & & 1547.66 & 0.4241 \\
$\mathbf{1 0}$ & $\mathbf{1 8 3 8 3 0 9}$ & $\mathbf{1 8 9 7 5 0}$ & & & 0.1824 \\
12 & 3966853 & & & $\mathbf{4 3 6 . 0 5 5 5}$ & $\mathbf{0 . 2 2 6 4}$ \\
22 & 1885851 & & & 594.9487 & 0.2822 \\
$\mathbf{3 3}$ & $\mathbf{1 0 8 6 8 3 4 8}$ & & -22019 & & $\mathbf{0 . 3 4 7 9}$ \\
34 & 123143 & 113436 & & & 0.2162 \\
$\mathbf{4 2}$ & $\mathbf{5 1 7 6 2 2 3}$ & & -9634.58 & & $\mathbf{0 . 3 1 1 4}$ \\
43 & 1140772 & & & -155.478 & 0.1978 \\
44 & 3999369 & & & -509.546 & 0.2222 \\
$\mathbf{4 5}$ & 4328480 & -158990 & & & 0.2749 \\
46 & 2213568 & & & -320.842 & 0.214 \\
49 & 67638 & 376288 & -16012 & & 0.4184 \\
$\mathbf{5 0}$ & $\mathbf{1 3 1 4 3 4 1 3}$ & $\mathbf{- 3 6 1 6 6 7}$ & & & $\mathbf{0 . 2 2 0 4}$ \\
51 & 4193280 & & & -739.289 & 0.417 \\
52 & 3527150 & & -9220.79 & & 0.2721 \\
53 & 3056220 & & & 1192.338 & 0.2844 \\
\hline
\end{tabular}

$\mathrm{R}^{2}=$ coefficient of determination. Spots highlighted in bold were selected for protein identification, as they showed frequency higher than $90 \%$ and $p<$ 0.05 in mixed model or regression analysis. gos = linear effect of gossypol concentration in diet; gos ${ }^{2}=$ quadratic effect of gossypol concentration in diet; gos $^{3}=$ cubic effect of gossypol concentration in diet.

that received whole cottonseed had less unsaturated fatty acids, conjugated linoleic acid (CLA) and vaccenic acid (Paim et al., 2014). The meat from lambs that did not receive cotton co-products had higher n-3 fatty acids, and also better n-6 to $\mathrm{n}-3$ ratio than meat from lambs that received cotton co-products (Paim et al., 2014). The 
Table 4 - Proteins differentially expressed in Longissmus dorsi muscle from lambs fed with cotton co-products identified by two-dimensional electrophoresis and mass spectrometry.

\begin{tabular}{|c|c|c|c|c|c|c|c|c|}
\hline Protein & $\begin{array}{l}\text { Experimental }{ }^{1} \\
\mathrm{kDa} / \mathrm{pl}\end{array}$ & $\begin{array}{l}\text { NCBI or SWISS-PROT } \\
\text { accession number }\end{array}$ & $\begin{array}{l}\text { MS/MS protein } \\
\text { score }\end{array}$ & Sequence coverage & Matched peptides ${ }^{2}$ & Ion score & $\mathrm{m} / \mathrm{z}$ & z \\
\hline & & & & $\%$ & & & & \\
\hline \multicolumn{9}{|c|}{ Actin, alpha skeletal muscle [Bos taurus] } \\
\hline \multirow[t]{4}{*}{ Spot 4} & $11.31 / 4.89$ & ACTS_BOVIN & 254 & 13 & (21)AGFAGDDAPR ${ }^{(30)}$ & 86 & 488.7235 & 2 \\
\hline & & & & & (42)HQGVMVGMGQK(52) & 46 & 586.2895 & 2 \\
\hline & & & & & (53)DSYVGDEAQSK(63) & 52 & 599.7650 & 2 \\
\hline & & & & & ${ }^{1988 V A P E E H P T L L T E A P L N P K(115) ~}$ & 30 & 652.6765 & 3 \\
\hline \multirow[t]{8}{*}{ Spot 12} & $22.66 / 5.42$ & gi|27819614 & 427 & 27 & ${ }^{198}$ VAPEEHPTLLTEAPLNPK ${ }^{(115)}$ & 27 & 652.6845 & 3 \\
\hline & & & & & ${ }^{(186)}$ DLTDYLMK ${ }^{(193)}$ & 32 & 507.7443 & 2 \\
\hline & & & & & ${ }^{(199)}$ GYSFVTTAER ${ }^{(208)}$ & 47 & 565.7781 & 2 \\
\hline & & & & & (241)SYELPDGQVITIGNER ${ }^{(256)}$ & 73 & 895.9522 & 2 \\
\hline & & & & & ${ }^{(294)}$ DLYANNVMSGGTTMYPGIADR ${ }^{(314)}$ & 76 & 1139.9984 & 2 \\
\hline & & & & & (318)EITALAPSTMK ${ }^{(328)}$ & 43 & 581.3148 & 2 \\
\hline & & & & & ${ }^{(331)|| A P P E R}{ }^{(337)}$ & 38 & 398.2374 & 2 \\
\hline & & & & & ${ }^{(362)}$ QEYDEAGPSIVHR ${ }^{(374)}$ & 92 & 750.8587 & 2 \\
\hline \multicolumn{9}{|c|}{ Alpha-actinin-3 [Ovis Áries] } \\
\hline \multirow[t]{10}{*}{ Spot 8} & $68.22 / 5.06$ & gi|426252090 & 599 & 12 & ${ }^{(418)}$ ASLHEAWTRR ${ }^{(426)}$ & 29 & 535.7727 & 2 \\
\hline & & & & & ${ }^{(427) G K E E M L S Q R}{ }^{(435)}$ & 48 & 539.2728 & 2 \\
\hline & & & & & (436)DYETASLQEVR(446) & 76 & 655.8167 & 2 \\
\hline & & & & & ${ }^{(581) G A I L G I Q G E I Q K(592) ~}$ & 37 & 613.8616 & 2 \\
\hline & & & & & (671)LAAGMAGSLEEQMAGLR ${ }^{(687)}$ & 109 & 860.9241 & 2 \\
\hline & & & & & ${ }^{(688)} Q Q E Q N I I N Y K(697)$ & 40 & 639.3274 & 2 \\
\hline & & & & & ${ }^{(720)} H_{T V Y S M E H I R}{ }^{(729)}$ & 44 & 430.2057 & 3 \\
\hline & & & & & (742)TINEVENQVLTR ${ }^{(753)}$ & 86 & 708.3787 & 2 \\
\hline & & & & & ${ }^{(757) G L S Q E Q L N E F R(767) ~}$ & 88 & 660.8319 & 2 \\
\hline & & & & & ${ }^{(851)}$ NYITAEELR ${ }^{(859)}$ & 53 & 554.7860 & 2 \\
\hline \multicolumn{9}{|c|}{ Troponin T, fast skeletal muscle [Ovis aries] } \\
\hline \multirow[t]{2}{*}{ Spot 5} & $15.71 / 4.96$ & gi|426258858 & 87 & 7 & (95)VDFDDIQK ${ }^{(102)}$ & 27 & 490.2419 & 2 \\
\hline & & & & & ${ }^{(108)}$ DLMELQALIDSHFEAR ${ }^{(123)}$ & 60 & 635.9118 & 3 \\
\hline \multirow[t]{3}{*}{ Spot 40} & $33.75 / 6.42$ & gi|426258858 & 222 & 13 & ${ }^{(193) A L S S M G A N Y S S Y L A K ~(207) ~}$ & 114 & 789.8764 & 2 \\
\hline & & & & & (249) ELWDTLYK ${ }^{(256)}$ & 24 & 534.2742 & 2 \\
\hline & & & & & $\begin{array}{l}\text { (257) } \text { LETDKFEYGEK }^{(267)} \\
\text { (273) YDIMNVR }^{(279)}\end{array}$ & $\begin{array}{l}48 \\
40\end{array}$ & $\begin{array}{l}679.8258 \\
463.7242\end{array}$ & $\begin{array}{l}2 \\
2\end{array}$ \\
\hline \multicolumn{9}{|c|}{ Fast skeletal muscle troponin T [Capra hircus] } \\
\hline \multirow[t]{5}{*}{ Spot 41} & $33.87 / 6.51$ & gi|347597734 & 309 & 21 & (62)VDFDDIQK ${ }^{(69)}$ & 31 & 490.2418 & 2 \\
\hline & & & & & ${ }^{(75)}$ DLMELQALIDSHFEAR ${ }^{(90)}$ & 74 & 635.3099 & 3 \\
\hline & & & & & ${ }^{(154) A L S S M G A N Y S S Y L A K ~}{ }^{(168)}$ & 100 & 789.8775 & 2 \\
\hline & & & & & (218)LETDKFEYGEK ${ }^{(228)}$ & 65 & 679.8278 & 2 \\
\hline & & & & & (234)YDITNLR (240) & 39 & 447.7354 & 2 \\
\hline \multicolumn{9}{|c|}{ Myosin light chain $1 / 3$, skeletal muscle isoform } \\
\hline \multirow[t]{2}{*}{ Spot 10} & $15.70 / 5.06$ & MYL1_BOVIN & 60 & 10 & ${ }^{(68) \mid T L S Q V G D V L R}{ }^{(78)}$ & 50 & 600.8533 & 2 \\
\hline & & & & & (152)HVLATLGEK(160) & 10 & 484.2826 & 2 \\
\hline \multicolumn{9}{|c|}{ Chain D, Bovine Mitochondrial F1-Atpase Complexed with Aurovertin B } \\
\hline \multirow[t]{11}{*}{ Spot 7} & $49.09 / 5.05$ & gi|1827812 & 1122 & 51 & ${ }^{(49)}$ LVLEVAQHLGESTVR ${ }^{(63)}$ & 47 & 550.9759 & 3 \\
\hline & & & & & (64)TIAMDGTEGLVR(75) & 95 & 639.8223 & 2 \\
\hline & & & & & ${ }^{(79)} V_{L D S G A P I R}(87)$ & 70 & 464.2671 & 2 \\
\hline & & & & & ${ }^{(88) \mid P V G P E T L G R}{ }^{(97)}$ & 60 & 519.7972 & 2 \\
\hline & & & & & ${ }^{(98) \mid M N V I G E P I D E R}{ }^{(109)}$ & 59 & 693.3576 & 2 \\
\hline & & & & & (143)VVDLLAPYAK(152) & 45 & 544.8226 & 2 \\
\hline & & & & & ${ }^{(156) \mid G L F G G A G V G K(166) ~}$ & 52 & 488.2822 & 2 \\
\hline & & & & & (167)TVLIMELINNVAK ${ }^{(179)}$ & 63 & 737.4200 & 2 \\
\hline & & & & & ${ }^{(180)}$ AHGGYSVFAGVGER(193) & 89 & 703.8450 & 2 \\
\hline & & & & & ${ }^{(196)}$ EGNDLYHEMIESGVINLK ${ }^{(213)}$ & 43 & 687.6683 & 3 \\
\hline & & & & & ${ }^{(219)}$ VALVYGQMNEPPGAR ${ }^{(233)}$ & 90 & 801.4119 & 2 \\
\hline
\end{tabular}


Table 4 - Continuation.

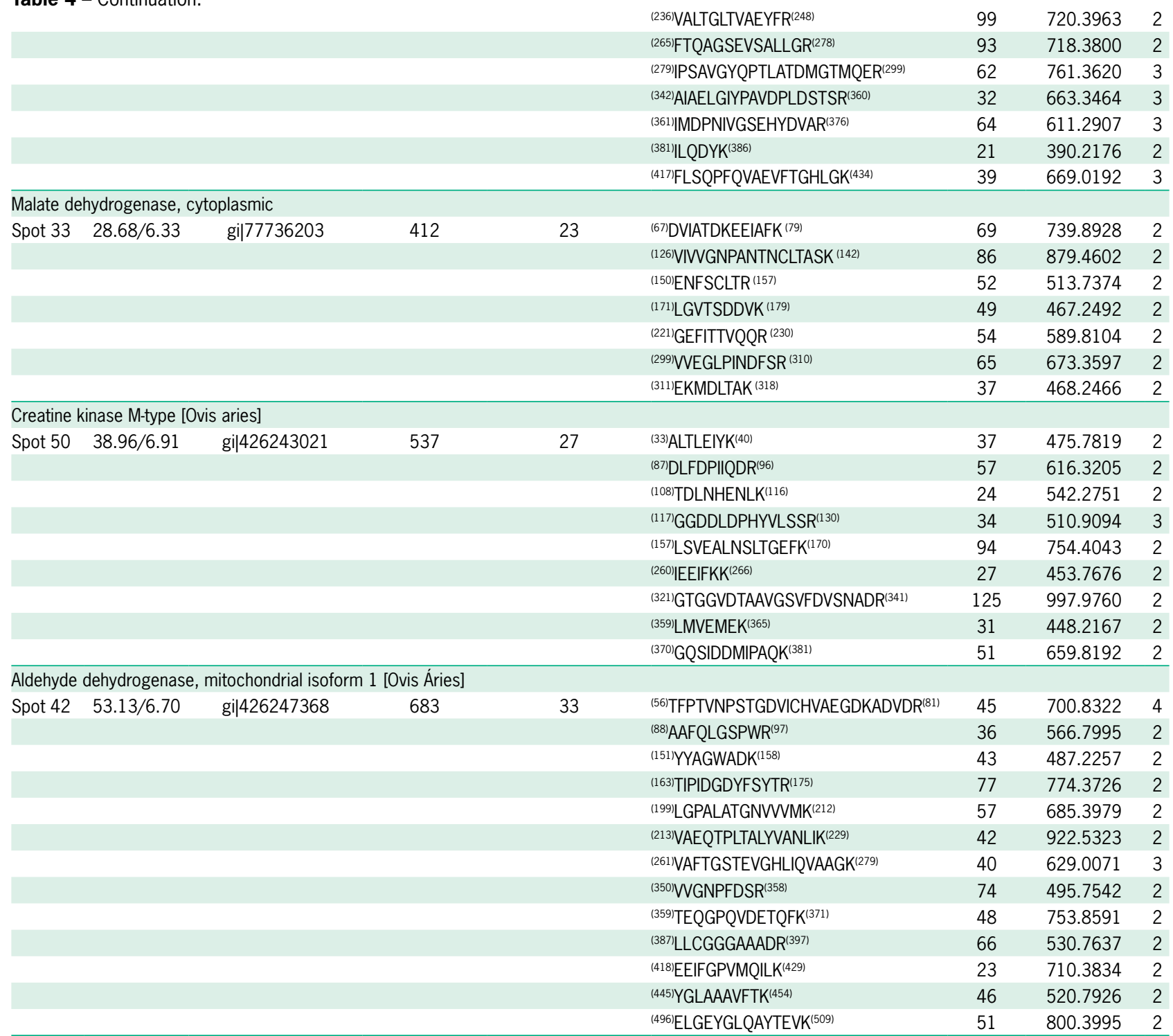

$\overline{\mathrm{MS}} / \mathrm{MS}$ = mass spectrometry/mass spectrometry; $\mathrm{NCBI}=$ National Center for Biotechnology Information; $\mathrm{pl}=$ isoelectric point; $\mathrm{m}=$ mass; $^{\mathrm{z}}=$ charge; $^{1}{ }^{E x p e r i m e n t a l}$ values were deduced from the 2D map by the PDQuest software package (version 7.3.0; Bio-Rad); ${ }^{2}$ Superscript numbers in parenthesis relate to the position of each peptide within the amino acid sequence of the complete protein, according to database search using Mascot search engine.

hematological and serum biochemical parameters remained within the reference range values established for lambs (Viana et al., 2015). Gossypol residues in the carcass were not detected and, therefore, it is reasonable to assume that gossypol concentration in meat was below 20 ppb (Viana et al., 2015).

The present study shows how feeding cotton coproducts can change the proteomic profile of meat. The proteomics approach enabled the identification of eight proteins of Longissimus dorsi altered by cottonseed coproducts in diet. The Longissimus dorsi comprised predominantly type II fibers (80\%) with $50 \%$ being type II B fibers. This muscle represents a uniquely anaerobic muscle, with major economic importance to the meat in- dustry (Baldwin et al., 2012). These proteomic changes can affect the physiological function of muscle in live animals and/or impair the muscle to meat conversion, which can promote modifications in organoleptic characteristics of meat.

Cotton co-products fed to lambs promoted an increase in ACTA1, ACTN3, TNNT3 and MYL1 in Longissimus dorsi, which are responsible for ATP binding and transport (ACTA1), actin and tropomyosin binding (ACTN3) and regulation of myosin (TNNT3 and MYL1), respectively. Therefore, cotton co-products fed to lambs affected the main factors involved in muscle contraction, mainly fast muscle function. Fast muscle activity is crucial to the decline of $\mathrm{pH}$ during the conversion of 
muscle to meat. A higher abundance of fast muscle proteins, as seen here in gossypol treated animals, was related to rapid $\mathrm{pH}$ decline, resulting in high drip loss (Andersen et al., 2005). If post mortem $\mathrm{pH}$ decreases rapidly, while muscle temperature is still high, myosin heads denature and shrink, which contribute to myofibrillar lateral shrinkage (Offer, 1991). The denatured myosin had a lower capacity for binding water, decreasing water holding capacity, which in extreme cases leads to pale, soft and exudative (PSE) meat (Offer, 1991).

There was a negative linear regression of gossypol in dehydrogenases enzymes. Consequently, the meat from animals fed cottonseed had the lowest abundance of these proteins. Cotton co-products decreased two enzymes involved in cell detoxification and cell protection processes (ALDH1B1 and MDH1). Gossypol is known to inhibit dehydrogenases including lactate dehydrogenase, malate dehydrogenase, glutamate dehydrogenase, alcohol dehydrogenase, glyceraldehyde-3-P dehydrogenase, aldehyde dehydrogenase, $11 \beta$-hydroxysteroidehydrogenase, $3 \alpha, 20 \beta$-hydroxysteroid dehydrogenase, 5a- reductase and glucose-6-P dehydrogenase (Chen et al., 2009; Van der Jagt et al., 2000; Zhang et al., 2009). Gossypol has the ability to selectively bind at the dinucleotide fold, promoting inhibition of these enzymes (Van der Jagt et al., 2000). Therefore, the lower ALDH level found in all the cottonseed fed rams may be associated with a low detoxification capacity, and could be related to other biological activities of gossypol, including anti-parasitic, anti-malarial, anti-HIV and anticancer (Zhang et al., 2009; 2012).

In summary, the abundance of four proteins (ACTA1, ACTN3, TNNT3 and MYL1) from the contractile apparatus, mainly fast muscle type, were increased by feeding cotton co-products to lambs. On the other hand, cotton co-products promoted a down-regulation of two enzymes related to different steps of ATP supply to the cell (CKM and ATP5B), which is needed for muscle contraction.

The main known gossypol targets are the glycolytic (ATP production) and dehydrogenase enzymes (Dao et al., 2000; Deck et al., 1999; Gizejewski et al., 2008). ACTA1, ACTN3 and TNNT3 are related mainly to the fast muscle type, which is a highly energy dependent cell (Garton et al., 2014; Seto et al., 2013; Huang et al., 2012). MYL1 is an ATP dependent protein (Polati et al., 2012). Lametsch et al. (2006) found that the intensity of both MYL1 and MYL2, measured $48 \mathrm{~h}$ after slaughter, was increased by compensatory growth, which indicated greater proteolytic activity postmortem. Probably, the contractile proteins were upregulated, aiming to equilibrate the lack of energy supply, and prevent losses in muscle function.

During the conversion of muscle to meat, $\mathrm{pH}$ decrease occurs due to the anaerobic conversion of glycogen resulting in a build-up of hydrogen ions through the formation of lactic acid (Dikeman and Devine, 2014). Depending on muscle type and glycogen concentration,
$\mathrm{pH}$ decreases from 7.0 in live muscle to $\mathrm{pH} 5.4$ to 6.3 (mean around 5.5-5.6) in meat (Dikeman and Devine, 2014). The gossypol effects on Longissimus dorsi proteins found in the current study seem to promote a low glycogen stock associated with a high fast-muscle function. These effects can promote fast glycogen consumption with fast $\mathrm{pH}$ decline during the first step of conversion of muscle to meat. However, they can lead to high $\mathrm{pH}$ at the end of the process due to the low glycogen stock at the beginning. Therefore, some problems can arise in meat processing and storage when the meat comes from cotton co-products-fed animals (mainly whole cottonseed). These problems could be biologically related to alterations in meat flavor; however, to confirm this hypothesis, further studies evaluating the associations between sensory properties and proteomic profile of meat are required.

\section{Conclusion}

Feeding cotton co-products to lambs changed the abundance of important muscle proteins, mainly related to fast muscle function. ATP synthesis and dehydrogenase enzymes were the main metabolic pathways affected by the cotton co-products diets. Therefore, gossypol had a negative impact on cell energy supply and, consequently, in order to maintain muscle function, the abundance of ATP dependent proteins (contractile apparatus) increased.

\section{Acknowledgments}

To the Conselho Nacional de Desenvolvimento Científico e Tecnológico (CNPq) and Ministério da Agricultura, Pecuária e Abastecimento (MAPA) (edital 64), Instituto Nacional de Ciência e Tecnologia de Informação Genético-Sanitária da Pecuária Brasileira (INCTPecuária), Coordenação de Aperfeiçoamento de Pessoal de Nivel Superior (CAPES) and Fundação de Amparo à Pesquisa do Estado de São Paulo (FAPESP) for providing financial support and scholarships, and the Instituto Federal Goiano for supporting the publication process. To Frederico B.M.B. Moreno, Ana Cristina O. MonteiroMoreira and Renato A. Moreira for performing the proteomic analysis.

\section{Authors' Contributions}

Conceptualization: Paim, T.P.; Souza, J.R.; McManus, C.; Louvandini, H. Live animal data acquisition: Paim, T.P.; Viana, P. Gossypol determination: Souza, J.R. Proteomic data acquisition: Van Tilburg, M.F.; Moura, A.A. Data analysis: Paim, T.P.; Van Tilburg, M.F. Design of Methodology: Paim, T.P.; Moura, A.A.; Souza, J.R.; McManus, C.; Abdalla, A.L.; Louvandini, H. Writing: Paim, T.P.; Louvandini, H. Proof reading and editing: Van Tilburg, M.F.; Moura, A.A.; Souza, J.R.; McManus, C.; Abdalla, A.L. 


\section{References}

Andersen, H.J.; Oksbjerg, N.; Young, J.F.; Therkildsen, M. 2005. Feeding and meat quality: a future approach. Meat Science 70: 543-554.

Baldwin, R.L.; Li, R.W.; Li, C.-J.J.; Thomson, J.M.; Bequette, B.J. 2012. Characterization of the longissimus lumborum transcriptome response to adding propionate to the diet of growing Angus beef steers. Physiological Genomics 44: 543550.

Botsoglou, N.A. 1991. Determination of "free" gossypol in cottonseed and cottonseed meals by second-derivative ultraviolet spectrophotometry. Journal of Agricultural and Food Chemistry 39: 478-482.

Bradford, M.M. 1976. Rapid and sensitive method for quantitation of microgram quantities of protein utilizing principle of protein-dye binding. Analytical Biochemistry 72: 248-254.

Chen, B.-B.; Lin, H.; Hu, G.-X.; Su, Y.; Zhou, H.-Y.; Lian, Q.Q.; Cai, H.; Hardy, D.O.; Gu, D.-Y.; Ge, R.-S. 2009. The $(+)$ - and (-)-gossypols potently inhibit human and rat 11ß-hydroxysteroid dehydrogenase type 2. The Journal of Steroid Biochemistry and Molecular Biology 113: 177-181.

Costa, D.P.B.; Roça, R.O.; Costa, Q.P.B.; Lanna, D.P.D.; Lima, E.S.; Barros, W.M. 2013. Meat characteristics of Nellore steers fed whole cottonseed. Revista Brasileira de Zootecnia 42: 183192.

Cranston, J.J.; Rivera, J.D.; Galyean, M.L.; Brashears, M.M.; Brooks, J.C.; Markham, C.E.; McBeth, L.J.; Krehbiel, C.R. 2006. Effects of feeding whole cottonseed and cottonseed products on performance and carcass characteristics of finishing beef cattle. Journal of Animal Science 84: 2186-2199.

Dao, V.T.; Gaspard, C.; Mayer, M.; Werner, G.H.; Nguyen, S.N.; Michelot, R.J. 2000. Synthesis and cytotoxicity of gossypol related compounds. European Journal of Medicinal Chemistry 35: 805-813.

Deck, L.M.; Chamblee, B.B.; Royer, R.E.; Hunsaker, L.A.; Van der Jagt, D.L. 1999. Inhibition of aldose reductase by gossypol and gossypol-related compounds. Advances in Experimental Medicine and Biology 463: 487-492.

Dikeman, M.; Devine, C. 2014. Encyclopedia of Meat Sciences. 2ed. Academic Press, San Diego, CA, USA.

Gadelha, I.C.N.; Fonseca, N.B.S.; Oloris, S.C.S.; Melo, M.M.; Soto-Blanco, B. 2014. Gossypol toxicity from cottonseed products. The Scientific World Journal 2014: 4-6.

Garton, F.C.C.; Seto, J.T.T.; Quinlan, K.G.R.G.; Yang, N.; Houweling, P.J.J.; North, K.N.N. 2014. $\alpha$-Actinin-3 deficiency alters muscle adaptation in response to denervation and immobilization. Human Molecular Genetics 23: 1879-1893.

Gizejewski, Z.; Szafranska, B.; Steplewski, Z.; Panasiewicz, G.; Ciereszko, A.; Koprowski, H. 2008. Cottonseed feeding delivers sufficient quantities of gossypol as a male deer contraceptive. European Journal of Wildlife Research 54: 469-477.

He, T.; Zhang, H.; Wang, J.; Wu, S.; Yue, H.; Qi, G. 2017. Proteomic comparison by ITRAQ combined with mass spectrometry of egg white proteins in laying hens (Gallus gallus) fed with soybean meal and cottonseed meal. PLoS One 12: $\mathrm{e} 0182886$.
Huang, M.; Huang, F.; Ma, H.; Xu, X.; Zhou, G. 2012. Preliminary study on the effect of caspase- 6 and calpain inhibitors on postmortem proteolysis of myofibrillar proteins in chicken breast muscle. Meat Science 90: 536542.

Lametsch, R.; Kristensen, L.; Larsen, M.R.; Therkildsen, M.; Oksbjerg, N.; Ertbjerg, P. 2006. Changes in the muscle proteome after compensatory growth in pigs. Journal of Animal Science 84: 918-924.

Ministério da Agricultura, Pecuária e Abastecimento [MAPA]. 1980. Regulation of the Industrial and Sanitary Insepction of Animal Food Products $=$ Regulamento da Inspeção Industrial e Sanitária de Produtos de Origem Animal. MAPA, Brasília, DF, Brazil (in Portuguese).

Moura, A.A.; Koc, H.; Chapman, D.A.; Killian, G.J. 2006. Identification of proteins in the accessory sex gland fluid associated with fertility indexes of dairy bulls: a proteomic approach. Journal of Andrology 27: 201-211.

Nutrients Requirement Council [NRC]. 2007. Nutrient Requirements of Small Ruminants: Sheep, Goats, Cervids, and New World Camelids. The National Academies Press, Washington, DC, USA.

Offer, G. 1991. Modelling of the formation of pale, soft and exudative meat: effects of chilling regime and rate and extent of glycolysis. Meat Science 30: 157-184.

Oliveira, C.H.A.; Silva, A.M.; Silva, L.M.; van Tilburg, M.F.; Fernandes, C.C.L.; Moura, A.A.; Moreno, F.B.M.B.; Monteiro-Moreira, A.C.O.; Moreira, R.A.; Bezerra, F.J.; Rondina, D. 2015. Meat quality assessment from young goats fed for long periods with castor de-oiled cake. Meat Science 106: 16-24.

Paim, T.P.; Viana, P.; Brandão, E.; Amador, S.; Barbosa, T.; Cardoso, C.; Dantas, A.M.M.; Souza, J.R.; McManus, C.; Abdalla, A.L.; Louvandini, H. 2014. Carcass traits and fatty acid profile of meat from lambs fed different cottonseed byproducts. Small Ruminant Research 116: 71-77.

Polati, R.; Menini, M.; Robotti, E.; Millioni, R.; Marengo, E.; Novelli, E.; Balzan, S.; Cecconi, D. 2012. Proteomic changes involved in tenderization of bovine Longissimus dorsi muscle during prolonged ageing. Food Chemistry 135: 20522069.

Rego, J.P.A.; Crisp, J.M.; Moura, A.A.; Nouwens, A.S.; Li, Y.; Venus, B.; Corbet, N.J.; Corbet, D.H.; Burns, B.M.; Boe-Hansen, G.B.; McGowan, M.R. 2014. Seminal plasma proteome of electroejaculated Bos indicus bulls. Animal Reproduction Science 148: 1-17.

Sanchez, J.-C.C.; Chiappe, D.; Converset, V.; Hoogland, C.; Binz, P.-A.A.; Paesano, S.; Appel, R.D.; Wang, S.; Sennitt, M.; Nolan, A.; Cawthorne, M.A.; Hochstrasser, D.F. 2001. The mouse SWISS-2D PAGE database: a tool for proteomics study of diabetes and obesity. Proteomics 1: 136-163.

Seto, J.T.; Quinlan, K.G.R.; Lek, M.; Zheng, X.F.; Garton, F.; MacArthur, D.G.; Hogarth, M.W.; Houweling, P.J.; Gregorevic, P.; Turner, N.; Cooney, G.J.; Yang, N.; North, K.N. 2013. ACTN3 genotype influences muscle performance through the regulation of calcineurin signaling. Journal of Clinical Investigation 123: 4255-4263. 
Silva, R.V.M.M.; Carvalho, G.G.P.; Pires, A.J.V.; Pereira, M.L.A.; Pereira, L.; Campos, F.S.; Perazzo, A.F.; Araújo, M.L.G.M.L.; Nascimento, C.O.; Santos, S.A.; Tosto, M.S.L.; Rufino, L.M.A.; Carvalho, B.M.A. 2016. Cottonseed cake in substitution of soybean meal in diets for finishing lambs. Small Ruminant Research 137: 183-188.

Van Tilburg, M.F.; Rodrigues, M.A.; Moreira, R.A.; Moreno, F.B.; Monteiro-Moreira, A.C.; Cândido, M.J.; Moura, A.A. 2013. Membrane-associated proteins of ejaculated sperm from Morada Nova rams. Theriogenology 79: 1247-1261.

Van der Jagt, D.L.; Deck, L.M.; Royer, R.E. 2000. Gossypol: prototype of inhibitors targeted to dinucleotide folds. Current Medicinal Chemistry 7: 479-498.

Viana, P.G.; Lima, P.M.T.; Paim, T.P.; Souza, J.R.; Dantas, A.M.M.; Pereira, E.F.; Gonçalves, V.; McManus, C.; Abdalla, A.L.; Louvandini, H. 2015. Gossypol was not detected in the longissimus muscle of lambs fed several forms of cottonseed. Animal Production Science 55: 812-817.
Wang, M.Z. 1987. Analysis of gossypol by high-performance liquid-chromatography. Journal of Ethnopharmacology 20: $1-11$.

Zhang, L.; Jiang, H.X.; Cao, X.X.; Zhao, H.Y.; Wang, F.; Cui, Y.X.; Jiang, B. 2009. Chiral gossypol derivatives: evaluation of their anticancer activity and molecular modeling. European Journal of Medicinal Chemistry 44: 3961-3972.

Zhang, Y.-S.S.; Yuan, J.; Fang, Z.-Z.Z.; Tu, Y.-Y.Y.; Hu, C.M.M.; Li, G.; Wang, L.; Deng, J.-P.P.; Yao, J.-J.J.; Li, H.-R.R. 2012. Gossypol exhibits a strong influence towards UDPglucuronosyltransferase (UGT) 1A1, 1A9 and 2B7-mediated metabolism of xenobiotics and endogenous substances. Molecules 17: 4896-4903. 